REVIEW

This paper is dedicated to the $70^{\text {th }}$ anniversary of the founding of Physiologia Bohemoslovaca (currently Physiological Research)

\title{
Adipose Tissue Macrophages and Atherogenesis - A Synergy With Cholesterolaemia
}

\author{
Rudolf POLEDNE ${ }^{1}$, Ivana KRALOVA LESNA ${ }^{1,2}$ \\ ${ }^{1}$ Laboratory for Atherosclerosis Research, Institute for Clinical and Experimental Medicine, Prague, \\ Czech Republic, ${ }^{2}$ Anaestesiology, Resuscitation and Intensive Care Unit, Military University \\ Hospital, Prague, Czech Republic
}

Received June 15, 2021

Accepted August 26, 2021

\begin{abstract}
Summary
Excessive LDL cholesterol concentration together with subclinical inflammation, in which macrophages play a central role, are linked pathologies. The process starts with the accumulation of macrophages in white adipose tissue and the switch of their polarization toward a pro-inflammatory phenotype. The proportion of pro-inflammatory macrophages in adipose tissue is related to the main risk predictors of cardiovascular disease. The cholesterol content of phospholipids of cell membranes seems to possess a crucial role in the regulation of membrane signal transduction and macrophage polarization. Also, different fatty acids of membrane phospholipids influence phenotypes of adipose tissue macrophages with saturated fatty acids stimulating pro-inflammatory whereas $\omega 3$ fatty acids antiinflammatory changes. The inflammatory status of white adipose tissue, therefore, reflects not only adipose tissue volume but also adipose tissue macrophages feature. The beneficial dietary change leading to an atherogenic lipoprotein decrease may therefore synergically reduce adipose tissue driven inflammation.
\end{abstract}

\section{Key words}

Inflammation • Adipose tissue macrophages • Plasma membrane - Cholesterol $\bullet \omega 3$ fatty acids

\section{Corresponding author}

Rudolf Poledne, IKEM, Videnska 1958/9, 14021 Prague, Czech Republic. E-mail: rudolf.poledne@ikem.cz

\section{Introduction}

Atherosclerosis develops as the result of a pathological interplay between increased inflow of cholesterol (either from LDL particles or lipoprotein remnants) into the arterial wall and local recruitment of monocytes (Tabas and Lichtman 2017). While cholesterol transport from the liver to extrahepatic tissue is critical for cell membrane formation, common plasma cholesterol levels in industrialized countries exceed physiological needs. This physiological mechanism worked satisfactorily for the overwhelming majority of individuals until the late $19^{\text {th }}$ century when LDL-cholesterol concentration increased due to substantial increase of animal fat consumption. The effect of this negative dietary change was nicely documented by long-term analysis of the lifespan in a large Dutch family with familial hypercholesterolemia (Sijbrands et al. 2001, Poledne and Zicha 2018). Increased their LDL-cholesterol levels were closely related to the proportion of pro-inflammatory macrophages in the white visceral adipose tissue and it is supposed to be a clear advantage to fight infectious diseases and, consequently longer life (until the $20^{\text {th }}$ century). By contrast, later increased consumption of saturated fatty acids (SAFA) markedly increases their LDL-cholesterol levels and shortens their life expectancy. A definite disadvantage of increased cholesterol levels due to increased cholesterol inflow into the arterial wall is that this process entails pro-inflammatory macrophage polarization (LemaireEwing et al. 2012, Poledne et al. 2016).

The dietary-induced inflow into the arterial wall works in synergy with pro-inflammatory macrophage polarization (Lemaire-Ewing et al. 2012, Poledne et al. 
2016). Whereas the causality between increased LDL-cholesterol levels and atherogenesis was demonstrated almost half a century ago (a successful decrease in cardiovascular disease (CVD) mortality through statin use), the causality between inflammation and atherogenesis - through effective reduction of myocardial infarction-related mortality with antibody against interleukin $1 \beta$, a key marker of pro-inflammatory status - was demonstrated only recently (Ridker et al. 2017) despite initial reports of increased CVD risk of individuals with increased CRP levels (Ridker et al. 1997). The interplay between low-grade inflammation and increased cholesterol levels was also nicely documented in the experimental model of apoE KO mice in which circulated monocytes enriched by cholesterol (only after a few days of the Western-type diet) are more likely to cross the arterial endothelium and invade the intima (Foster et al. 2015). The situation is more complex in men, it is widely accepted that low-grade inflammation induced by adipose tissue plays the most important role.

Although visceral adiposity was shown to raise the risk of CVD as early as the 1940s (Vague 1947), hard evidence for the pathological potential of adipose tissue macrophages was lacking for decades. Step by step, starting from the newly described metabolic aspect of the role of adipose tissue (in addition to energy storage and adipocyte hypertrophy) (Avogaro et al. 1965) through metabolic disease as the direct effect of obesity to the term "metabolic syndrome" (Reaven 1994), adipose tissue is now considered an endocrine organ (Bays 2011). Today, the crucial role of adipose tissue in the development of low-grade inflammation is beyond any doubt. The close interconnection between metabolic and immune dysfunction made researchers coin the term immunometabolism, which is now commonly used to describe obesity-related pathologies of adipose tissue.

\section{Adipose tissue as an immune organ}

In addition to adipokine regulating primarily metabolic function, white adipose tissue is also an important source of adipokines implicated in the regulation of immune and inflammatory responses. One of these is resistin produced in humans mostly by adipose tissue macrophages. Resistin has primarily proinflammatory activity with an indirect effect on metabolism, mediated through increased expression of pro-inflammatory cytokines, in particular tumor necrosis factor $\alpha(\mathrm{TNF} \alpha)$ and IL-6. Another adipokine, visfatin, is secreted by several cell types including adipocytes, macrophages and endothelial cells and has been shown to play an important role in vascular cell inflammation through the NF- $\mathrm{BB}$ pathway and endothelial adhesion molecule expression (Lee et al. 2009). Other primarily pro-inflammatory (retinol-binding protein 4) and antiinflammatory (omentin-1) adipokines have been discovered and, given the interconnection of metabolic and immune processes, they have also been implicated in the pathogenesis of CVD (Landecho et al. 2019). Besides, adipose tissue produces a large number of cytokines and chemokines that are not tissue-specific and are inseparably involved in the immune response. It is through their secretion that adipose tissue is systematically involved in the activity of an individual's immune system under both physiological and pathological conditions.

The most thoroughly investigated cytokine secreted by adipose tissue is TNF $\alpha$. The predominant source of this cytokine are macrophages, however, the expression of TNF $\alpha$ in adipose tissue increases with obesity (Hotamisligil et al. 1995). This pivotal cytokine stimulates other pro-inflammatory cytokines, mainly IL-6 and IL-1 $\beta$ (Chen and Goeddel 2002), and also, downregulates adiponectin secretion (Bruun et al. 2003). Its role in diet-induced insulin resistance has been conclusively demonstrated and was one of the first proven links between obesity, inflammation and metabolism (Hotamisligil and Spiegelman 1994). TNF $\alpha$ is also involved in atherogenesis as it induces endothelial dysfunction with an obvious link to loss of endothelial protective role (Virdis et al. 2019).

In healthy individuals, the participation of adipocyte-derived IL-6 to its systemic levels are estimated to be about one third of total production. Although IL-6 was traditionally believed to possess clearly pro-inflammatory activity and considered a risk factor for the development of type 2 diabetes in humans (Pradhan et al. 2001), this view has been recently challenged (Wueest and Konrad 2020).

On the other hand, the anti-inflammatory cytokine interleukin 10 (IL-10) is also secreted by adipose tissue (mainly by regulatory $\mathrm{T}$ cells and M2 macrophages) to balance the niveau of local inflammation in situ (Juge-Aubry et al. 2005), its plasma levels have been suggested as a biomarker of obesityrelated metabolic disorders (Kulshrestha et al. 2018).

Similarly, a host of other important cytokines have been implicated in adipose tissue inflammation with 
their respective roles recently summarized (Unamuno et al. 2018).

\section{Focus on Macrophages}

Macrophages, the essential components of innate immunity, are one of the most abundant and heterogeneous groups of immune cells, with scavenging of pathogens and damaged cells long regarded as their main function. However, any individual is facing constantly changing threats and macrophages are perfectly adapted to cope with them to maintain the specific tissue environment and to restore physiological state. The original assumption was that monocytes that cross the arterial wall and enter tissues to be transformed to macrophages are the sole source of tissue macrophages. However, this concept was refuted long ago as a proportion of tissue macrophages appears to be deposited in tissues before birth and maintained by selfrenewal (Lumeng et al. 1972).

Given the broad spectrum of macrophage functions and processes they are involved in, which range from sensing pathogens through removal of cell debris, modulation of inflammation, production of key cytokines to suppression of inflammation in the healing phase, it is not surprising that a highly variable receptor profile with corresponding functional activity exists. Not only are there detectable differences between these tissue-specific macrophages, macrophage subtypes can also be identified within a single type of tissue. Still, there has not been unanimity about the plasticity of fully mature resident macrophages (Lavin et al. 2014, van de Laar et al. 2016), which is also why it is virtually impossible to comprehensively examine this entire group of cells.

A widely accepted approach is to classify macrophages by the stimuli leading to their differentiation and functional activity (Murray et al. 2014). Macrophage subtypes should be perceived as a continuum with diverse patterns of inflammatory and metabolic pathways as changes in tissue microenvironments drive their alteration to participate in restoring homeostasis. This concept, however, may be a simplified one to elucidate macrophage function. On the one hand, M1 phenotype polarization is driven by interferon $\gamma$ (INF $\gamma)$ and LPS stimulation and is characterized by high expression of of pro-inflammatory cytokines (IL-1 $\beta, \mathrm{TNF} \alpha, \mathrm{IL}-6$ ) and a high capacity to produce reactive radicals. These characteristics impart the M1 subpopulation potent phagocytic, microbicidal and tumoricidal activity. By contrast, M2 macrophage polarization is induced by IL-4 and IL-10. M2 macrophages display with a limited capacity to kill pathogens and due to high expression of anti-inflammatory and regulatory cytokines are involved in tissue remodelling, promotion of regenerative processes, formation of the extracellular matrix and also tumor progression.

\section{Phenotypes of adipose tissue macrophages}

Macrophages are the most numerous immune cells in stromal vascular fraction and play an important role in both physiological and pathological conditions of adipose tissue. Their numbers increase with obesity, in experimental models they make up $40 \%$ of nonadipocyte cells in adipose tissue (Weisberg et al. 2003). The increase in adipose tissue mass associated with increased secretion of adhesion molecules and chemokines (Takahashi et al. 2003) results in the migration of immune cells, predominantly monocytes, into adipose tissue. Indeed, the expression of monocyte chemoattractant protein (MCP-1) in adipose tissue preceded metabolic sequels of obesity ( $\mathrm{Xu}$ et al. 2003). While MCP-1 is formed mainly by adipocytes, it is also activated macrophages which contribute to MCP-1 production (as a result of interaction of SAFA with Toll-like receptor (TLR) 4 (see below). This feedback stimulates macrophage infiltration and acceleration of inflammation in adipose tissue (Bai and Sun 2015). The final number of macrophages results not only from their entry into adipose tissue, local proliferation, apoptosis and differentiation from pre-adipocytes (Charrière et al. 2003) but, presumably, also from macrophage outflow from tissues (Amano et al. 2014, Ramkhelawon et al. 2014).

Originally, macrophage accumulation was considered a marker of pro-inflammatory status of adipose tissue, however, as mentioned above, the macrophage population is highly variable and may evoke different responses. In physiological, non-obese adipose tissue, macrophages tend to polarize - under the influence of the so-called Th2 cellular response (characterized by the production of typical cytokines such as IL-4, IL-5 and IL-13) - predominantly towards the M2 phenotype. These M2 macrophages of physiological adipose tissue express arginase, inhibit iNOS activity, and produce anti-inflammatory cytokines such as IL-10, which maintain adipocyte insulin sensitivity by inhibiting TNF $\alpha$ 
(Smallie et al. 2010) thus significantly affecting the local microenvironment and adipocyte function. The metabolic demands of M2 macrophages are provided with long-term sustainable energy sources mainly through fatty acid oxidation, tricarboxylic acid cycle and mitochondrial respiration. The preferential energy substrate of M2 macrophages is oxidative phosphorylation. However, excess of M2 macrophages is also associated with aberrant fibrogenesis (Hou et al. 2018), which may hinder adipose tissue remodelling in obesity. The pro-inflammatory environment in obese adipose tissue leads to rearrangement toward prevalence of M1 macrophages (Thomas and Apovian 2017). Metabolic brake in tricarboxylic acid cycle (Jha et al. 2015) was identified in these proinflammatory macrophages resulting in a shift toward increased glucose anaerobic glycolysis as a key source of energy even under aerobic conditions. This M1 macrophage predominance results in the disruption of the functional state of adipocytes (Jager et al. 2007, Permana et al. 2006) reducing insulin sensitivity already in clinically healthy overweight individuals (Rydén et al. 2019). It is the ration of diverse adipose tissue macrophage subtypes which determines the inflammatory status of adipose tissue. Furthermore, although the concept of M1 pro-inflammatory and M2 anti-inflammatory macrophages is accepted for adipose tissue macrophages (ATM), their phenotypic determination is very uncertain and differences between men and animal models exist. The above facts likely contribute to significant contradictions in published data, where pro-inflammatory characteristics of adipose tissue such as obesity were associated with the expression of anti-inflammatory markers (Fjeldborg et al. 2014, Zeyda et al. 2007), in addition, macrophages both expressing pro- and antiinflammatory phenotypic or functional features have also been reported (Bourlier et al. 2008, Zeyda et al. 2007).

The relationship between adipocytes and macrophages appears to be reciprocal, as paracrine interactions between adipocytes and macrophages have been demonstrated, in which free fatty acids (FFA) and $\mathrm{TNF} \alpha$ appear to play a key role (Suganami et al. 2005). $\mathrm{TNF} \alpha$ release from pro-inflammatory macrophages trigger inflammatory changes in adipocytes. These changes include not only FFA release that aggravates inflammation in adipocytes but, also, MCP-1 secretion entailing further infiltration of monocytes from the bloodstream. It has also been recently documented in an in vitro model that the interaction of macrophages and adipocytes led to an increase in the production of oxygen radicals in macrophages, with triglyceride content in adipocytes increasing by more than $70 \%$ (Nimri et al. 2019), again confirming the possibility of significant paracrine interaction of these cells in fat in situ. The intercellular environment in adipose tissue is rich in glucose, insulin, palmitate and chemically (oxidation and glycation) modified metabolites and therefore several other tissue-specific macrophage phenotypes with unique properties have been identified in adipose tissues ( $\mathrm{Li}$ et al. 2020). Several metabolic pathways have been directly linked to macrophage polarization, giving rise to metabolically activated macrophages (MAM). Saturated fatty acids have been shown to stimulate TLR4 on macrophages and adipocytes (McKernan et al. 2020) and to activate NF-kB (Rocha et al. 2016). Lipolysis of triglycerides making up the intracellular content of FFA in adipocytes and consequently their release. An increased intracellular content of saturated FFA (e.g., palmitic acid) leads to changes in the endoplasmic reticulum (similar to other plasma membranes), referred to as endoplasmic reticulum stress (ERS) and subsequent activation of significant pro-inflammatory pathways (associated with activation of c-Jun-N terminal kinase and NF-KB) (Hotamisligil 2010). According to published data, MAM can be characterized by high expression of ATP-binding cassette transporter A1, perilipin-2 and CD36. A direct effect of environment, which resembles that of adipose tissue, on macrophage polarization was clearly shown (Kratz et al. 2014) highlighting the importance of $\mathrm{CD} 36$. The $\mathrm{CD} 36$ receptor is a scavenger receptor with recognized proatherogenic effects (Park 2014). CD36 expression appears to be regulated at the level of transcription, posttranscriptional modifications (miRNAs) and other processes (Tian et al. 2020). Including this marker we were able to identify specific macrophage subpopulation with close relationship to main risk factor of atherosclerosis (Kralova Lesna et al. 2018). Our results confirmed the link between adipose tissue macrophages, CD36 overexpression and hypercholesterolemia (Poledne et al. 2016) on the one hand, and the fatty acid spectrum in adipose tissue membranes on the other (Poledne et al. 2019). It is clear that the fatty acids released from hypertrophied adipocytes also serve as ligands for TLR4 and contribute to further deterioration of physiological regulation (Suganami et al. 2005). Moreover, hypertrophied adipocytes have been shown to increase the expression of arachidonic acid converting enzymes to pro-inflammatory 
mediators (Mothe-Satney et al. 2012). The size of macrophages compared to that of hypertrophied adipocytes renders their phagocytosis impossible and the crown-like structures consisting of several macrophages surrounding the adipocyte with extracellular lysosomal compartments represent the typical histological pattern of obese adipose tissue. These and other processes are involved in the development of pro-inflammatory status of adipose tissue associated with its dysfunction. However, a double-faced feature that includes the beneficial role of MAM in diet-induced obesity has been proposed based on their involvement in dead adipocyte clearance (Coats et al. 2017).

Oxidation and glycation of lipoproteins change their properties. These modified particles are perceived by macrophages as what is referred to as dangerassociated molecular patterns (through TLR and CD36) activating the inflammatory pathways and macrophage differentiation (Seo et al. 2015) and giving rise to antioxidant macrophages (Mox). These Mox, which can be differentiated from both M1 and M2 macrophages by treatment with oxidized lipids, are characterized by upregulation of antioxidant enzymes and reduced phagocytic and chemotactic capacity (Kadl et al. 2010).

Another macrophage phenotype identified in adipose tissue are iron-rich macrophages, which are characterized by an anti-inflammatory and iron-recycling gene expression profile (Orr et al. 2014). These authors demonstrated, in vivo, obesity-evoked reduction of the iron content of specific adipose tissue macrophages and, also, reduction of the gene expression of iron importers in these macrophages.
A specific feature of M2 macrophages in white adipose tissue may also be their production of catecholamines and the induction of changes referred to as browning, i.e. the expression of uncoupling protein-1 (Villarroya et al. 2018). Although the important role of M2 macrophages in this process has been repeatedly confirmed (Nguyen et al. 2011, Qiu et al. 2014, Rajasekaran et al. 2019), other authors have questioned it (Fischer et al. 2017).

\section{Adipose tissue cell membrane composition and inflammation}

The potential of dietary fats to influence systemic inflammation has been supported by numerous published data (see review Calder 2017). To give an example - in a well-controlled experiment, 15 healthy female volunteers (peri- and postmenopausal) and employees of our Institute were included in a randomized double crossover study (Kralova Lesna et al. 2013). The participants were supplied, over a period of 3 weeks, a diet either rich in SAFA or polyunsaturated fatty acids (PUFA) (40\% energy of total fat) with a wash-out period in between. A comparison of the final datasets of both dietary regimens revealed an increase in LDL cholesterol levels (after lipoprotein fraction isolation by ultracentrifugation) by almost $1 \mathrm{mmol}$ after the SAFA diet. Also, HDL cholesterol levels increased significantly after SAFA compared to the PUFA diet (Kralova Lesna et al. 2013). In addition to lipoprotein changes, the SAFA diet also induced systemic inflammation assessed by high-sensitive CRP. a

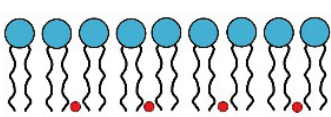

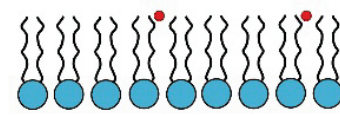

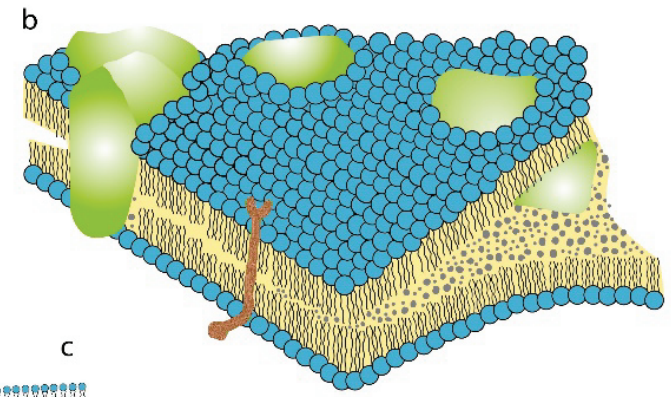

Fig. 1. a) Plasma membrane phosphorlipid (and cholesterol - red circle) structure of the outer and inner parts. b) Cell surface covered and uncovered by the raft (green parts). Transmembrane position of the specific receptor (brown). c) Specific receptor and its location in the coated pits. 
It has been documented recently that the cell membrane structure is related to the pro-inflammatory activity of adipose tissue (Poledne et al. 2019). After four decades of systematic research, the exact structure of the plasma membrane remains poorly understood. The structure and dynamics of plasma membrane have been analyzed using physicochemical techniques (Devaux and Hermann 2012). The cell membrane is a semipermeable bilayer that consist mainly of phospholipids enveloping the cell and delimiting cytoplasm and its intracellular organelles from the cell surroundings. The cell membrane proteins are attached loosely within the membrane and are allowed to defuse laterally or to rotate about. Signal from the extracellular space to cytosol (and back) has been well described, but much uncertainty remains over the role of a surface lipid raft (Simons and Gerl 2010). A lipid raft is defined as a liquid-moving cholesterolsphingolipid and protein enriched domain compartmentalizing cellular processes (Pike 2006), Fig 1. However, lipid rafts relevance and even existence remains elusive, because no method is currently available to document its presence on the surface of living cells (Levental et al. 2020). It has been conclusively established that lipid rafts are only present in the parts of the cell membrane where important cellular processes take place (Levental et al. 2020). Still, an effect of some substances on membrane function has been demonstrated. Specifically, the caveolin proteins bind tightly to cholesterol in the cell membrane affecting its function (Parton and Simons 2007) whereas the palmitoleate molecule, which is surprisingly plentiful in the cell membrane, substantially modulates the inflammatory response (Medina et al. 2006). The important role of palmitoleate in the stimulation of pro-inflammatory polarization of adipose tissue macrophages was recently documented (Poledne et al. 2019), yet its exact mechanism remains unknown. However, the majority of studies have logically focused on the effect of cholesterol within the plasma membrane and its function.

It is of interest that, while even markers of low-grade inflammation (CRP, TNF $\alpha$, Il-18) may disappear after successful weight loss, adipose tissue infiltration with macrophages will persist (Ara et al. 2020).

\section{Cholesterol and the plasma membrane}

The cholesterol molecule within the plasma membrane has been shown to play a most important role in various cell functions (Varshney et al. 2016). For example, cholesterol enrichment of the plasma membrane results in its lower fluidity which may, in turn, prompt the signaling pathway to promote the formation of some solid tumors such as breast and prostate cancer (HryniewiczJankowska et al. 2019). An increase in cholesterol content in the cell membrane will enhance the proinflammatory effect of macrophages through the TLR's system (but not only through TLR4).

The reported data conclusively documenting the close correlation between the levels of intravascular cholesterol and inflammation confirm the bi-directional effect of cholesterol molecules and pro-inflammatory macrophages, as suggested by both various experimental models and tissue culture (Tall and Yvan-Charvet 2015, Yvan-Charvet et al. 2008) and (Medbury et al. 2015), respectively. This close relationship of non-HDL cholesterol and pro-inflammatory status of human visceral adipose tissue is in line with the summarized data on cholesterol and inflammation in experimental models fed a high-fat, high-cholesterol diet (Tall and YvanCharvet 2015).

Cholesterol enrichment of the plasma membrane as a consequence of an increase in plasma cholesterol levels has been implicated in adipose tissue dysfunction (Aguilar and Fernandez 2014), local systemic inflammation (Busnelli et al. 2013) and pro-inflammatory macrophage polarization in adipose tissue. The plasma levels of both non-HDL cholesterol and LDL cholesterol have been shown to correlate with the proportion of pro-inflammatory macrophages in human adipose tissue (Poledne et al. 2016). While cholesterol exchange between lipoproteins and macrophage surface has not been demonstrated to date, it was recently shown for red blood cells (Lai et al. 2019). On the other hand, an inverse correlation between alternatively polarized macrophages and non-HDL cholesterol levels has also been reported (Poledne et al. 2016).

Importantly, cholesterol density within the cell membrane is not distributed homogeneously. Caveolae are enriched by cholesterol compared to the neighboring parts of the membrane (Ortegren et al. 2004). Cholesterol depletion in the caveolae may completely destruct their function (Rothberg et al. 1992). The effects of diet on low-grade inflammation can be explained by plasma membrane enrichment with the cholesterol molecule (Scalia, 2013).

Given the above, one may conclude that lipids and the cholesterol molecule in particular - play a most 
important role in cell membrane function (Simons and Gerl 2010). The so-called "pleotropic effects of statins" may be therefore explained by cholesterol lowering which, in turn, slows cholesterol transport to the lipid raft thus affecting macrophage polarization. An increase in the mole percentage of cholesterol and different proportions of saturated and $\omega 3$ PUFA in the lipid raft may be able to change the caveolae of circulating monocytes and their ability to enter the arterial wall and to mature into residential macrophages. Cholesterol molecules play a multifunctional role in atherogenesis (Pirillo et al. 2018) not only based on to their increased levels in circulating LDL particles but, also, in the immune response based on signal transduction in inflammation (Lemaire-Ewing et al. 2012).

\section{Effect of fatty acid composition of the plasma membrane}

Just another and most interesting aspect of adipose tissue inflammation are the different proportions of palmitate and $\omega 3$ fatty acids in the plasma membrane. Evidence has been mounting over the last decade that locally increasing SAFA levels could be directly related to adipose tissue pro-inflammatory status (Siri-Tarino et al. 2010). Palmitate has been shown to enhance the proinflammatory activity in adipocyte tissue culture (Ajuwon and Spurlock 2005) through NF-kB and substantially increase IL-6 production. A similar effect was documented in human macrophage culture (Laine et al. 2007) where laurate, palmitate, and stearate stimulated NF- $\mathrm{KB}$ activation, whereas $\omega 3$ PUFA were able to inhibit it. It is not clear yet whether this pro-inflammatory effect of SAFA is produced by palmitate itself or is the result of palmitoleate (desaturation product of palmitate by stearyl-CoA desaturase). The highly elegant methodological approach proposed by Suganami (Suganami et al. 2007), who used a co-culture of adipocytes and macrophages, demonstrated that NF- $\mathrm{kB}$ activation was much greater compared with seen with separate cultures of both cell types serving as controls. The interplay between adipocytes and macrophages in co-culture activated the NF- $\kappa B$ pathway in macrophages increasing $\mathrm{TNF} \alpha$ production which, in turn, induced adipocyte lipolysis and SAFA release. The endogenous free fatty acids (predominantly palmitate) released from co-cultured adipocytes were able to activate the NF- $\mathrm{KB}$ pathway in macrophages and, possibly, increase TNF $\alpha$ production. Quite surprisingly, the adverse effects of
SAFA on the innate immune response may be inhibited by high-density lipoproteins (Zhang et al. 2017). Mechanisms whereby SAFA activate the regulatory role of Toll-like receptor 4 include their numbers, protein dimerization, and changes in lipid rafts. All of these three mechanisms have been shown to enhance the inflammatory effects of SAFA (Lee and Hwang 2006).

The proportions of saturated and unsaturated fatty acids (mainly $\omega 3$ PUFA) in cell membrane phospholipids have been found to be responsible for inflammatory changes. Studies with high intake of fish oil tested the hypothesis that the established effects of $\omega 3$ eicosepentaenoic fatty acid (EPA) could afford protection against CVD (Calder et al. 2002). However, such a protective effect has not been conclusively confirmed as, while some studies reported a beneficial effect in terms of coronary heart disease prevention, the outcomes of other studies were just the opposite. The effect of fish oil has been shown to depend on the quality of fish oil products. The negative results of dietary intervention may be attributable to increased contents of oxidized fish oil and increased proportions of SAFA in dietary supplements (Manson et al. 2019, Mason et al. 2020). Use of fish oil capsules originally employed to treat high plasma triglyceride level brought very inconsistent results (as reported earlier). On the contrary, in the Reduction of Cardiovascular Events With Icosapent Ethyl-Intervention Trial (REDUCE-IT), pure eicosopentaenic acid administration resulted in triglyceride lowering (Bhatt 2019). An additional $25 \%$ reduction in ischemic heart disease has been documented in patients with residual risk (while already on statin treatment) in this trial. There are several possibilities to explain this successful effect of a pure molecule. Among these, an $\omega 3$ fatty acids induced decrease in monocyte adhesion or antithrombotic effect are plausible, besides, an effect of $\omega 3 \mathrm{FA}$ incorporation to the plasma membrane leading to a decrease in the proportion of pro-inflammatory macrophages has also been demonstrated (Poledne et al. 2019).

Increased consumption of dietary EPA results in their accelerated incorporation into plasma membranes of monocytes and macrophages (Calder et al. 2002) and, eventually, inflammation and production of cytokines decreasing monocyte and macrophage adhesiveness to the endothelium (Mason et al. 2020). The result is less substrate for eicosanoid synthesis from arachidonic acid known to promote inflammation.

Unlike $\alpha$-linolenic and eicosopentaenic acids, the SAFA in the plasma membrane are associated with 
increased adipose tissue macrophage polarization to proinflammatory status (Poledne et al. 2019) likely due to reduced plasma membrane fluidity (Dunbar et al. 2015). Increased proportions of SAFA in the plasma membranes in adipose tissue was shown to increase the proportion of pro-inflammatory macrophages in human visceral adipose tissue (Poledne et al. 2019).

Part of the data reported above were obtained by analysis of adipose tissue in various animal models. It is always difficult, if not impossible, to extrapolate experimental data from animal models to human pathology. For example, the issue of macrophage specification is even more complicated as similarities between human (CD14, CD16 or CD163) and mice (CCR5, Cx3CR1) surface receptor function are only assumed and difficult to establish. Given the above, no clear-cut definition of the pro-inflammatory M1 and antiinflammatory M2 phenotypes has been proposed and their respective roles in atherogenesis and inflammation remain poorly understood (Calder 2017).

\section{The pro-inflammatory effect of free fatty acids in adipose tissue}

The relationship between adipose tissue and atherosclerosis was explained by the "sick fat" concept proposed in the early 21st century (Bays 2011) based on the unprecedented increase in the incidence of obesity during the last decades of the 20th century. An important passive role of adipose tissue lasted 100000 years, when it served as a reserve metabolic source of energy for man during frequent periods of fasting or even starvation due to extremely limited energy availability. This situation changed dramatically during the last century. Due to easy access to food for most of the population around the world, amount of body fat increased with the increasing prevalence of obesity. This applies not only to industrialized nations but, also, to most regions the developing world. The real fasting period during the day practically disappeared in most people.

With widely available energy, lipolysis induced by cyclic ATP continues to deliver FFA to other tissues despite adequate energy supply from the intestine. In the absence of adequate amount of energy produced in the liver or muscle tissue, these FFA increase their plasma levels. Chronically elevated FFA levels impair insulin sensitivity (Boden and Shulman 2002) and their return to adipose tissue. Almost a third of the plasma FFA undergoes re-esterification (Nye et al. 2008) to triglycerides within adipose tissue in the process requiring additional energy supply (Izumi 2012). The remaining FFA are trapped in other organs increasing triglyceride levels in the muscle, liver and even pancreas. There are data documenting triglyceride accumulation in Langerhans cells, which triggers insufficient insulin production. Similarly, triglycerides tend to accumulate in the liver leading to the development of non- alcoholic liver steatohepatitis (NASH) (Cusi 2009).

A more detrimental process was documented in adipose tissue residential macrophages (Wong et al. 2019) where the FFA stimulate their surface Toll-like receptor (Wong et al. 2019) setting off an intracellular cascade leading to $\mathrm{NF}-\kappa \mathrm{B}$ activation in cytosol, promoting inflammation and production of cytokines in the nucleus (IL-6, TNF $\alpha$, IL-1 $\beta$, and others) (Blüher 2016, Wang et al. 2017). Consequently, adipose tissue becomes more increasingly infiltrated by macrophages (Moreno-Indias et al. 2016), even in individuals with normal body weight. Adding further complexity to the picture, unsaturated FFA inhibit the saturated FFA-induced pro-inflammatory effect (Bernardi et al. 2018).

It is of interest that, while even markers of lowgrade inflammation (CRP, TNF $\alpha$, Il-18) may disappear after successful weight loss, adipose tissue infiltration with macrophages will persist (Ara et al. 2020).

\section{Conclusions}

The risk of ectopic fat involvement in the development of cardiovascular disease was documented more than half a century ago. Nowadays we understand that the negative effect of enlarged adipose tissue occurs mainly through inflammation, with adipose tissue macrophages playing a pivotal role in this process. FFAs released from adipocytes activate adipose tissue macrophages through TLR, NF- $\kappa \mathrm{B}$ stimulation, and proinflammatory cytokine secretion driving the proinflammatory status of the whole body. The causality of the relationship of the pro-inflammatory status to atherosclerosis development was proved using human monoclonal antibodies targeting IL-1 $\beta$. The composition of the plasma membrane of adipose tissue macrophages serves as a playground in which signal proteins activate inflammation. Increased cholesterol content in the plasma membrane resulting from the interaction with pathologically increased plasma lipoproteins stimulates the pro-inflammatory polarization of macrophages. This 
similar effect is driven by increased proportions of palmitate and palmitoleate in cell membrane phospholipids. On the other hand, increased proportions of $\alpha$-linolenic acid and other $\omega 3$ fatty acids in plasma membrane phospholipids decrease the proportion of proinflammatory macrophages in adipose tissue. As different role of SAFA and PUFA is similar to their roles in the regulation of specific LDL receptors and, consequently, plasma LDL cholesterol levels, it is intriguing to speculate that these processes act together. It supports the hypothesis of the complex effect of the replacement of animal fat by vegetable fat, where lowering plasma LDL-cholesterol levels and decreasing pro-inflammatory status works in synergy.

\section{Conflict of Interest}

There is no conflict of interest.

\section{Acknowledgements}

The research was supported by a Ministry of Health of the Czech Republic grant (NU20-01-00022). All rights reserved.

\section{References}

AGUILAR D, FERNANDEZ ML: Hypercholesterolemia induces adipose dysfunction in conditions of obesity and nonobesity. Adv Nutr 5: 497-502, 2014. https://doi.org/10.3945/an.114.005934

AJUWON KM, SPURLOCK ME: Palmitate activates the NF-kappaB transcription factor and induces IL-6 and TNFalpha expression in 3T3-L1 adipocytes. J Nutr 135: 1841-6, 2005. https://doi.org/10.1093/jn/135.8.1841

AMANO SU, COHEN JL, VANGALA P, TENCEROVA M, NICOLORO SM, YAWE JC, SHEN Y, CZECH MP, AOUADI M: Local proliferation of macrophages contributes to obesity-associated adipose tissue inflammation. Cell Metab 19, 2014. https://doi.org/10.1016/j.cmet.2013.11.017

ARA I, AUERBACH P, LARSEN S, MATA E, STALLKNECHT B, PLOUG T, PRATS C, HELGE JW: Low-Grade Inflammation Is Not Present in Former Obese Males but Adipose Tissue Macrophage Infiltration Persists. Biomedicines 8, 2020. https://doi.org/10.3390/biomedicines8050123

AVOGARO P, CREPALDI G, ENZI G, TIENGO A: Metabolic aspects of essential obesity. (in Italian) Epatologia 11: 226-238, 1965.

BAI Y, SUN Q: Macrophage recruitment in obese adipose tissue. Obes Rev 16: 127-136, 2015. https://doi.org/10.1111/obr.12242

BAYS HE: Adiposopathy is "sick fat" a cardiovascular disease? J Am Coll Cardiol 57: 2461-2473, 2011. https://doi.org/10.1016/j.jacc.2011.02.038

BERNARDI S, MARCUZZI A, PISCIANZ E, TOMMASINI A, FABRIS B: The Complex Interplay between Lipids, Immune System and Interleukins in Cardio-Metabolic Diseases. Int J Mol Sci 19, 2018. https://doi.org/10.3390/ijms19124058

BLÜHER M: Adipose tissue inflammation: a cause or consequence of obesity-related insulin resistance? Clin Sci (Lond) 130: 1603-14, 2016. https://doi.org/10.1042/CS20160005

BODEN G, SHULMAN GI: Free fatty acids in obesity and type 2 diabetes: defining their role in the development of insulin resistance and beta-cell dysfunction. Eur J Clin Invest 32 Suppl 3: 14-23, 2002. https://doi.org/10.1046/j.1365-2362.32.s3.3.x

BOURLIER V, ZAKAROFF-GIRARD A, MIRANVILLE A, DE BARROS S, MAUMUS M, SENGENES C, GALITZKY J, LAFONTAN M, KARPE F, FRAYN KN, BOULOUMIE A: Remodeling phenotype of human subcutaneous adipose tissue macrophages. Circulation 117: 806-815, 2008. https://doi.org/10.1161/CIRCULATIONAHA.107.724096

BRUUN JM, LIHN AS, VERDICH C, PEDERSEN SB, TOUBRO S, ASTRUP A, RICHELSEN B: Regulation of adiponectin by adipose tissue-derived cytokines: in vivo and in vitro investigations in humans. Am J Physiol Endocrinol Metab 285: E527-E533, 2003. https://doi.org/10.1152/ajpendo.00110.2003

BUSNELLI M, MANZINI S, FROIO A, VARGIOLU A, CERRITO MG, SMOLENSKI RT, GIUNTI M, CINTI A, ZANNONI A, LEONE BE, FORNI M, BACCI ML, BIASI GM, GIOVANNONI R, LAVITRANO M: Diet induced mild hypercholesterolemia in pigs: local and systemic inflammation, effects on vascular injury - rescue by high-dose statin treatment. PLoS One 8: e80588, 2013. https://doi.org/10.1371/journal.pone.0080588 
CALDER PC: Omega-3 fatty acids and inflammatory processes: from molecules to man. Biochem Soc Trans 45: 1105-1115, 2017. https://doi.org/10.1042/BST20160474

CALDER PC, YAQOOB P, THIES F, WALLACE FA, MILES EA: Fatty acids and lymphocyte functions. Br J Nutr 87 Suppl 1: S31-48, 2002. https://doi.org/10.1079/BJN2001455

COATS BR, SCHOENFELT KQ, BARBOSA-LORENZI VC, PERIS E, CUI C, HOFFMAN A, ZHOU G, FERNANDEZ S, ZHAI L, HALL BA, HAKA AS, SHAH AM, REARDON CA, BRADY MJ, RHODES CJ, MAXFIELD FR, BECKER L: Metabolically Activated Adipose Tissue Macrophages Perform Detrimental and Beneficial Functions during Diet-Induced Obesity. Cell Rep 20: 3149-3161, 2017. https://doi.org/10.1016/j.celrep.2017.08.096

CUSI K: Nonalcoholic fatty liver disease in type 2 diabetes mellitus. Curr Opin Endocrinol Diabetes Obes 16: 141-149, 2009. https://doi.org/10.1097/MED.0b013e3283293015

DEVEAUX PF, HERRMANN A: Methods for the determination of lipid transmembrane distribution and movement in biological membranes. In: Transmembrane dynamics of lipids ProQuest Ebook Central. PF Devaux (ed), John Wiley \& Sons, Inc., 2011. pp 3-24. https://doi.org/10.1002/9781118120118.ch1

DUNBAR RL, NICHOLLS SJ, MAKI KC, ROTH EM, ORLOFF DG, CURCIO D, JOHNSON J, KLING D, DAVIDSON MH: Effects of omega-3 carboxylic acids on lipoprotein particles and other cardiovascular risk markers in high-risk statin-treated patients with residual hypertriglyceridemia: a randomized, controlled, double-blind trial. Lipids Health Dis 14: 98, 2015. https://doi.org/10.1186/s12944-015-0100-8

FISCHER K, RUIZ HH, JHUN K, FINAN B, OBERLIN DJ, VAN DER HEIDE V, KALINOVICH AV, PETROVIC N, WOLF Y, CLEMMENSEN C, SHIN AC, DIVANOVIC S, BROMBACHER F, GLASMACHER E, KEIPERT S, JASTROCH M, NAGLER J, SCHRAMM KW, MEDRIKOVA D, COLLDEN G, WOODS SC, HERZIG S, HOMANN D, JUNG S, NEDERGAARD J, CANNON B, TSCHÖP MH, MÜLLER TD, BUETTNER C: Alternatively activated macrophages do not synthesize catecholamines or contribute to adipose tissue adaptive thermogenesis. Nat Med 23: 623-630, 2017. https://doi.org/10.1038/nm.4316

FJELDBORG K, PEDERSEN SB, MOLLER HJ, CHRISTIANSEN T, BENNETZEN M, RICHELSEN B: Human adipose tissue macrophages are enhanced but changed to an anti-inflammatory profile in obesity. J Immunol Res 2014, 2014. https://doi.org/10.1155/2014/309548

FOSTER GA, XU L, CHIDAMBARAM AA, SODERBERG SR, ARMSTRONG EJ, WU H, SIMON SI: CD11c/CD18 Signals very late antigen-4 activation to initiate foamy monocyte recruitment during the onset of hypercholesterolemia. J Immunol 195: 5380-92, 2015. https://doi.org/10.4049/jimmunol.1501077

HOTAMISLIGIL GS: Endoplasmic reticulum stress and the inflammatory basis of metabolic disease. Cell 140: 900-917, 2010. https://doi.org/10.1016/j.cell.2010.02.034

HOTAMISLIGIL GS, SPIEGELMAN BM: Tumor necrosis factor alpha: a key component of the obesity-diabetes link. Diabetes 43: 1271-1278, 1994. https://doi.org/10.2337/diabetes.43.11.1271

HOTAMISLIGIL GS, ARNER P, CARO JF, ATKINSON RL, SPIEGELMAN BM: Increased adipose tissue expression of tumor necrosis factor-alpha in human obesity and insulin resistance. J Clin Invest 95: 2409-15, 1995. https://doi.org/10.1172/JCI117936

HOU J, SHI J, CHEN L, LV Z, CHEN X, CAO H, XIANG Z, HAN X: M2 macrophages promote myofibroblast differentiation of LR-MSCs and are associated with pulmonary fibrogenesis. Cell Commun Signal 16: 89, 2018. https://doi.org/10.1186/s12964-018-0300-8

HRYNIEWICZ-JANKOWSKA A, AUGOFF K, SIKORSKI AF: The role of cholesterol and cholesterol-driven membrane raft domains in prostate cancer. Exp Biol Med (Maywood) 244: 1053-1061, 2019. https://doi.org/10.1177/1535370219870771

CHARRIĖRE G, COUSIN B, ARNAUD E, ANDRÉ M, BACOU F, PENICAUD L, CASTEILLA L: Preadipocyte conversion to macrophage. Evidence of plasticity. J Biol Chem 278: 9850-9855, 2003. https://doi.org/10.1074/jbc.M210811200

CHEN G, GOEDDEL DV: TNF-R1 signaling: a beautiful pathway. Science 296: 1634-1635, 2002. https://doi.org/10.1126/science.1071924

IZUMI T: Adipose cell and lipid turnovers in obesity and insulin resistance. Diabetology International 3: 184-186, 2012. https://doi.org/10.1007/s13340-012-0092-9 
JAGER J, GRÉMEAUX T, CORMONT M, LE MARCHAND-BRUSTEL Y, TANTI JF: Interleukin-1beta-induced insulin resistance in adipocytes through down-regulation of insulin receptor substrate-1 expression. Endocrinology 148: 241-251, 2007. https://doi.org/10.1210/en.2006-0692

JHA AK, HUANG SC, SERGUSHICHEV A, LAMPROPOULOU V, IVANOVA Y, LOGINICHEVA E, CHMIELEWSKI K, STEWART KM, ASHALL J, EVERTS B, PEARCE EJ, DRIGGERS EM, ARTYOMOV MN: Network intergration of parallel metabolic and transcriptional data reveals metabolic modules that regulate macrophage polarization. Immunity 42: 419-430, 2015. https://doi.org/10.1016/j.immuni.2015.02.005

JUGE-AUBRY CE, SOMM E, PERNIN A, ALIZADEH N, GIUSTI V, DAYER JM, MEIER CA: Adipose tissue is a regulated source of interleukin-10. Cytokine 29: 270-274, 2005. https://doi.org/10.1016/j.cyto.2004.10.017

KADL A, MEHER AK, SHARMA PR, LEE MY, DORAN AC, JOHNSTONE SR, ELLIOTT MR, GRUBER F, HAN J, CHEN W, KENSLER T, RAVICHANDRAN KS, ISAKSON BE, WAMHOFF BR, LEITINGER N: Identification of a novel macrophage phenotype that develops in response to atherogenic phospholipids via Nrf2. Circ Res 107: 737-46, 2010. https://doi.org/10.1161/CIRCRESAHA.109.215715

KRALOVA LESNA I, SUCHANEK P, BRABCOVA E, KOVAR J, MALINSKA H, POLEDNE R: Effect of different types of dietary fatty acids on subclinical inflammation in humans. Physiol Res 62: 145-152, 2013. https://doi.org/10.33549/physiolres.932439

KRALOVA LESNA I, PETRAS M, CEJKOVA S, KRALOVA A, FRONEK J, JANOUSEK L, THIEME F, TYLL T, POLEDNE R: Cardiovascular disease predictors and adipose tissue macrophage polarization: Is there a link? Eur J Prev Cardiol 25: 328-334, 2018. https://doi.org/10.1177/2047487317743355

KRATZ M, COATS BR, HISERT KB, HAGMAN D, MUTSKOV V, PERIS E, SCHOENFELT KQ, KUZMA JN, LARSON I, BILLING PS, LANDERHOLM RW, CROUTHAMEL M, GOZAL D, HWANG S, SINGH PK, BECKER L: Metabolic dysfunction drives a mechanistically distinct proinflammatory phenotype in adipose tissue macrophages. Cell Metab 20: 614-25, 2014. https://doi.org/10.1016/j.cmet.2014.08.010

KULSHRESTHA H, GUPTA V, MISHRA S, MAHDI AA, AWASTHI S, KUMAR S: Interleukin-10 as a novel biomarker of metabolic risk factors. Diabetes Metab Syndr 12: 543-547, 2018. https://doi.org/10.1016/j.dsx.2018.03.019

LAI SJ, OHKAWA R, HORIUCHI Y, KUBOTA T, TOZUKA M: Red blood cells participate in reverse cholesterol transport by mediating cholesterol efflux of high-density lipoprotein and apolipoprotein A-I from THP-1 macrophages. Biol Chem 400: 1593-1602, 2019. https://doi.org/10.1515/hsz-2019-0244

LANDECHO MF, TUERO C, VALENTÍ V, BILBAO I, DE LA HIGUERA M, FRÜHBECK G: Relevance of leptin and other adipokines in obesity-associated cardiovascular risk. Nutrients 11, 2019. https://doi.org/10.3390/nu11112664

LAVIN Y, WINTER D, BLECHER-GONEN R, DAVID E, KEREN-SHAUL H, MERAD M, JUNG S, AMIT I: Tissue-resident macrophage enhancer landscapes are shaped by the local microenvironment. Cell 159: 1312-1326, 2014. https://doi.org/10.1016/j.cell.2014.11.018

LEE JY, HWANG DH: The modulation of inflammatory gene expression by lipids: mediation through Toll-like receptors. Mol Cells 21: 174-85, 2006. https://doi.org/10.1096/fasebj.21.5.A365

LEE WJ, WU CS, LIN H, LEE IT, WU CM, TSENG JJ, CHOU MM, SHEU WH: Visfatin-induced expression of inflammatory mediators in human endothelial cells through the NF-kappaB pathway. Int J Obes (Lond) 33: 465-472, 2009. https://doi.org/10.1038/ijo.2009.24

LEMAIRE-EWING S, LAGROST L, NÉEL D: Lipid rafts: a signalling platform linking lipoprotein metabolism to atherogenesis. Atherosclerosis 221: 303-310, 2012. https://doi.org/10.1016/j.atherosclerosis.2011.10.016

LEVENTAL I, LEVENTAL KR, HEBERLE FA: Lipid Rafts: Controversies Resolved, Mysteries Remain. Trends Cell Biol 30: 341-353, 2020. https://doi.org/10.1016/j.tcb.2020.01.009

LI Y, YUN K, MU R: A review on the biology and properties of adipose tissue macrophages involved in adipose tissue physiological and pathophysiological processes. Lipids Health Dis 19: 164, 2020. https://doi.org/10.1186/s12944-020-01342-3 
MANSON JE, COOK NR, LEE IM, CHRISTEN W, BASSUK SS, MORA S, GIBSON H, ALBERT CM, GORDON D, COPELAND T, D'AGOSTINO D, FRIEDENBERG G, RIDGE C, BUBES V, GIOVANNUCCI EL, WILLETT WC, BURING JE: Marine $\omega 3$ fatty acids and prevention of cardiovascular disease and cancer. N Engl J Med 380: 23-32, 2019. https://doi.org/10.1056/NEJMoa1811403

MASON RP, LIBBY P, BHATT DL: Emerging mechanisms of cardiovascular protection for the omega-3 fatty acid eicosapentaenoic acid. Arterioscler Thromb Vasc Biol 40: 1135-1147, 2020. https://doi.org/10.1161/ATVBAHA.119.313286

MCKERNAN K, VARGHESE M, PATEL R, SINGER K: Role of TLR4 in the induction of inflammatory changes in adipocytes and macrophages. Adipocyte 9: 212-222, 2020. https://doi.org/10.1080/21623945.2020.1760674

MEDINA FA, DE ALMEIDA CJ, DEW E, LI J, BONUCCELLI G, WILLIAMS TM, COHEN AW, PESTELL RG, FRANK PG, TANOWITZ HB, LISANTI MP: Caveolin-1-deficient mice show defects in innate immunity and inflammatory immune response during Salmonella enterica serovar Typhimurium infection. Infect Immun 74: 6665-74, 2006. https://doi.org/10.1128/IAI.00949-06

MORENO-INDIAS I, OLIVA-OLIVERA W, OMISTE A, CASTELLANO-CASTILLO D, LHAMYANI S, CAMARGO A, TINAHONES FJ: Adipose tissue infiltration in normal-weight subjects and its impact on metabolic function. Transl Res 172: 6-17 e3, 2016. https://doi.org/10.1016/j.trs1.2016.01.002

MOTHE-SATNEY I, FILLOUX C, AMGHAR H, PONS C, BOURLIER V, GALITZKY J, GRIMALDI PA, FÉRAL CC, BOULOUMIÉ A, VAN OBBERGHEN E, NEELS JG: Adipocytes secrete leukotrienes: contribution to obesity-associated inflammation and insulin resistance in mice. Diabetes 61: 2311-2319, 2012. https://doi.org/10.2337/db11-1455

MURRAY PJ, ALLEN JE, BISWAS SK, FISHER EA, GILROY DW, GOERDT S, GORDON S, HAMILTON JA, IVASHKIV LB, LAWRENCE T, LOCATI M, MANTOVANI A, MARTINEZ FO, MEGE JL, MOSSER DM, NATOLI G, SAEIJ JP, SCHULTZE JL, SHIREY KA, SICA A, SUTTLES J, UDALOVA I, VAN GINDERACHTER JA, VOGEL SN, WYNN TA: Macrophage activation and polarization: nomenclature and experimental guidelines. Immunity 41: 14-20, 2014. https://doi.org/10.1016/j.immuni.2014.06.008

NGUYEN KD, QIU Y, CUI X, GOH YP, MWANGI J, DAVID T, MUKUNDAN L, BROMBACHER F, LOCKSLEY RM, CHAWLA A: Alternatively activated macrophages produce catecholamines to sustain adaptive thermogenesis. Nature 480: 104-108, 2011. https://doi.org/10.1038/nature10653

NIMRI L, GRAJEDA-IGLESIAS C, VOLKOVA N, AVIRAM M: Pro-atherogenic and pro-oxidant crosstalk between adipocytes and macrophages. Eur J Nutr 58: 879-893, 2019. https://doi.org/10.1007/s00394-018-1729-7

NYE C, KIM J, KALHAN SC, HANSON RW: Reassessing triglyceride synthesis in adipose tissue. Trends Endocrinol Metab 19: 356-361, 2008. https://doi.org/10.1016/j.tem.2008.08.003

ORR JS, KENNEDY A, ANDERSON-BAUCUM EK, WEBB CD, FORDAHL SC, ERIKSON KM, ZHANG Y, ETZERODT A, MOESTRUP SK, HASTY AH: Obesity alters adipose tissue macrophage iron content and tissue iron distribution. Diabetes 63: 421-432, 2014. https://doi.org/10.2337/db13-0213

ORTEGREN U, KARLSSON M, BLAZIC N, BLOMQVIST M, NYSTROM FH, GUSTAVSSON J, FREDMAN P, STRÅLFORS P: Lipids and glycosphingolipids in caveolae and surrounding plasma membrane of primary rat adipocytes. Eur J Biochem 271: 2028-2036, 2004. https://doi.org/10.1111/j.1432-1033.2004.04117.x

PARK YM: CD36, a scavenger receptor implicated in atherosclerosis. Exp Mol Med 46: e99, 2014. https://doi.org/10.1038/emm.2014.38

PARTON RG, SIMONS K: The multiple faces of caveolae. Nat Rev Mol Cell Biol 8: 185-194, 2007. https://doi.org/10.1038/nrm2122

PERMANA PA, MENGE C, REAVEN PD: Macrophage-secreted factors induce adipocyte inflammation and insulin resistance. Biochem Biophys Res Commun 341: 507-514, 2006. https://doi.org/10.1016/j.bbrc.2006.01.012

PIKE LJ: Rafts defined: a report on the Keystone Symposium on Lipid Rafts and Cell Function. J Lipid Res 47: 15971598, 2006. https://doi.org/10.1194/jlr.E600002-JLR200

PIRILLO A, BONACINA F, NORATA GD, CATAPANO AL: The Interplay of Lipids, Lipoproteins, and Immunity in Atherosclerosis. Curr Atheroscler Rep 20: 12, 2018. https://doi.org/10.1007/s11883-018-0715-0

POLEDNE R, ZICHA J: Human genome evolution and development of cardiovascular risk factors through natural selection. Physiol Res 67: 155-163, 2018. https://doi.org/10.33549/physiolres.933885 
POLEDNE R, KRALOVA LESNA I, KRALOVA A, FRONEK J, CEJKOVA S: The relationship between non-HDL cholesterol and macrophage phenotypes in human adipose tissue. J Lipid Res 57: 1899-1905, 2016. https://doi.org/10.1194/jlr.P068015

POLEDNE R, MALINSKA H, KUBATOVA H, FRONEK J, THIEME F, KAUEROVA S, LESNA IK: Polarization of Macrophages in Human Adipose Tissue is Related to the Fatty Acid Spectrum in Membrane Phospholipids. Nutrients 12, 2019. https://doi.org/10.3390/nu12010008

PRADHAN AD, MANSON JE, RIFAI N, BURING JE, RIDKER PM: C-reactive protein, interleukin 6, and risk of developing type 2 diabetes mellitus. Jama 286: 327-34, 2001. https://doi.org/10.1001/jama.286.3.327

QIU Y, NGUYEN KD, ODEGAARD JI, CUI X, TIAN X, LOCKSLEY RM, PALMITER RD, CHAWLA A: Eosinophils and type 2 cytokine signaling in macrophages orchestrate development of functional beige fat. Cell 157: 1292-1308, 2014. https://doi.org/10.1016/j.cell.2014.03.066

RAJASEKARAN M, SUL OJ, CHOI EK, KIM JE, SUH JH, CHOI HS: MCP-1 deficiency enhances browning of adipose tissue via increased M2 polarization. J Endocrinol 242: 91-101, 2019. https://doi.org/10.1530/JOE-19$\underline{0190}$

RAMKHELAWON B, HENNESSY EJ, MENAGER M, RAY TD, SHEEDY FJ, HUTCHISON S, WANSCHEL A, OLDEBEKEN S, GEOFFRION M, SPIRO W, MILLER G, MCPHERSON R, RAYNER KJ, MOORE KJ: Netrin-1 promotes adipose tissue macrophage retention and insulin resistance in obesity. Nat Med 20: 377-384, 2014. https://doi.org/10.1038/nm.3467

REAVEN GM: Syndrome X: 6 years later. J Intern Med Suppl 736: 13-22, 1994.

RIDKER PM, CUSHMAN M, STAMPFER MJ, TRACY RP, HENNEKENS CH: Inflammation, aspirin, and the risk of cardiovascular disease in apparently healthy men. $\mathrm{N}$ Engl J Med 336: 973-979, 1997. https://doi.org/10.1056/NEJM199704033361401

RIDKER PM, EVERETT BM, THUREN T, MACFADYEN JG, CHANG WH, BALLANTYNE C, FONSECA F, NICOLAU J, KOENIG W, ANKER SD, KASTELEIN JJP, CORNEL JH, PAIS P, PELLA D, GENEST J, CIFKOVA R, LORENZATTI A, FORSTER T, KOBALAVA Z, VIDA-SIMITI L, FLATHER M, SHIMOKAWA H, OGAWA H, DELLBORG M, ROSSI PRF, TROQUAY RPT, LIBBY P, GLYNN RJ: Antiinflammatory therapy with Canakinumab for atherosclerotic disease. N Engl J Med 377: 1119-1131, 2017. https://doi.org/10.1056/NEJMoa1707914

ROCHA DM, CALDAS AP, OLIVEIRA LL, BRESSAN J, HERMSDORFF HH: Saturated fatty acids trigger TLR4-mediated inflammatory response. Atherosclerosis 244: 211-215, 2016. https://doi.org/10.1016/j.atherosclerosis.2015.11.015

ROTHBERG KG, HEUSER JE, DONZELL WC, YING YS, GLENNEY JR, ANDERSON RG: Caveolin, a protein component of caveolae membrane coats. Cell 68: 673-682, 1992. https://doi.org/10.1016/0092-8674(92)90143$\underline{Z}$

RYDÉN M, PETRUS P, ANDERSSON DP, MEDINA-GÓMEZ G, ESCASANY E, CORRALES CORDÓN P, DAHLMAN I, KULYTÉ A, ARNER P: Insulin action is severely impaired in adipocytes of apparently healthy overweight and obese subjects. J Intern Med 285: 578-588, 2019. https://doi.org/10.1111/joim.12887

SEO JW, YANG EJ, YOO KH, CHOI IH: Macrophage Differentiation from Monocytes Is Influenced by the Lipid Oxidation Degree of Low Density Lipoprotein. Mediators Inflamm 2015: 235797, 2015. https://doi.org/10.1155/2015/235797

SIJBRANDS EJ, WESTENDORP RG, DEFESCHE JC, DE MEIER PH, SMELT AH, KASTELEIN JJ: Mortality over two centuries in large pedigree with familial hypercholesterolaemia: family tree mortality study. Bmj 322 : 1019-1023, 2001. https://doi.org/10.1136/bmj.322.7293.1019

SIMONS K, GERL MJ: Revitalizing membrane rafts: new tools and insights. Nat Rev Mol Cell Biol 11: 688-99, 2010. https://doi.org/10.1038/nrm2977

SIRI-TARINO PW, SUN Q, HU FB, KRAUSS RM: Meta-analysis of prospective cohort studies evaluating the association of saturated fat with cardiovascular disease. Am J Clin Nutr 91: 535-546, 2010. https://doi.org/10.3945/ajcn.2009.27725 
SMALLIE T, RICCHETTI G, HORWOOD NJ, FELDMANN M, CLARK AR, WILLIAMS LM: IL-10 inhibits transcription elongation of the human TNF gene in primary macrophages. J Exp Med 207: 2081-8, 2010. https://doi.org/10.1084/jem.20100414

SUGANAMI T, NISHIDA J, OGAWA Y: A paracrine loop between adipocytes and macrophages aggravates inflammatory changes: role of free fatty acids and tumor necrosis factor alpha. Arterioscler Thromb Vasc Biol 25, 2005. https://doi.org/10.1161/01.ATV.0000183883.72263.13

SUGANAMI T, TANIMOTO-KOYAMA K, NISHIDA J, ITOH M, YUAN X, MIZUARAI S, KOTANI H, YAMAOKA S, MIYAKE K, AOE S, KAMEI Y, OGAWA Y: Role of the Toll-like receptor 4/NF-kappaB pathway in saturated fatty acid-induced inflammatory changes in the interaction between adipocytes and $\begin{array}{lllllll}\text { macrophages. } & \text { Arterioscler } & \text { Thromb } & \text { Vasc } & \text { Biol }\end{array}$ https://doi.org/10.1161/01.ATV.0000251608.09329.9a

TABAS I, LICHTMAN AH: Monocyte-macrophages and T cells in atherosclerosis. Immunity 47: 621-634, 2017. https://doi.org/10.1016/j.immuni.2017.09.008

TAKAHASHI K, MIZUARAI S, ARAKI H, MASHIKO S, ISHIHARA A, KANATANI A, ITADANI H, KOTANI H: Adiposity elevates plasma MCP-1 levels leading to the increased CD11b-positive monocytes in mice. J Biol Chem 278: 46654-60, 2003. https://doi.org/10.1074/jbc.M309895200

TALL AR, YVAN-CHARVET L: Cholesterol, inflammation and innate immunity. Nat Rev Immunol 15: 104-116, 2015. https://doi.org/10.1038/nri3793

THOMAS D, APOVIAN C: Macrophage functions in lean and obese adipose tissue. Metabolism 72: 120-143, 2017. https://doi.org/10.1016/j.metabol.2017.04.005

TIAN K, XU Y, SAHEBKAR A, XU S: CD36 in Atherosclerosis: Pathophysiological Mechanisms and Therapeutic Implications. Curr Atheroscler Rep 22: 59, 2020. https://doi.org/10.1007/s11883-020-00870-8

UNAMUNO X, GÓMEZ-AMBROSI J, RODRÍGUEZ A, BECERRIL S, FRÜHBECK G, CATALÁN V: Adipokine dysregulation and adipose tissue inflammation in human obesity. Eur J Clin Invest 48: e12997, 2018. https://doi.org/10.1111/eci.12997

VAN DE LAAR L, SAELENS W, DE PRIJCK S, MARTENS L, SCOTT CL, VAN ISTERDAEL G, HOFFMANN E, BEYAERT R, SAEYS Y, LAMBRECHT BN, GUILLIAMS M: Yolk sac macrophages, fetal liver, and adult monocytes can colonize an empty niche and develop into functional tissue-resident macrophages. Immunity 44: 755-68, 2016. https://doi.org/10.1016/j.immuni.2016.02.017

VARSHNEY P, YADAV V, SAINI N: Lipid rafts in immune signalling: current progress and future perspective. Immunology 149: 13-24, 2016. https://doi.org/10.1111/imm.12617

VILLARROYA F, CEREIJO R, VILLARROYA J, GAVALDÀ-NAVARRO A, GIRALT M: Toward an understanding of how immune cells control brown and beige adipobiology. Cell Metab 27: 954-961, 2018. https://doi.org/10.1016/j.cmet.2018.04.006

VIRDIS A, COLUCCI R, BERNARDINI N, BLANDIZZI C, TADDEI S, MASI S: Microvascular endothelial dysfunction in human obesity: role of TNF- $\alpha$. J Clin Endocrinol Metab 104: 341-348, 2019. https://doi.org/10.1210/jc.2018-00512

WANG C, HA X, LI W, XU P, GU Y, WANG T, WANG Y, XIE J, ZHANG J: Correlation of TLR4 and KLF7 in inflammation induced by obesity. Inflammation 40: 42-51, 2017. https://doi.org/10.1007/s10753-016-0450-Z

WEISBERG SP, MCCANN D, DESAI M, ROSENBAUM M, LEIBEL RL, FERRANTE AW, JR: Obesity is associated with macrophage accumulation in adipose tissue. J Clin Invest 112: 1796-808, 2003. https://doi.org/10.1172/JCI200319246

WONG SK, CHIN KY, IMA-NIRWANA S: Toll-like receptor as a molecular link between metabolic syndrome and inflammation: a review. Curr Drug Targets 20: 1264-1280, 2019. https://doi.org/10.2174/1389450120666190405172524

WUEEST S, KONRAD D: The controversial role of IL-6 in adipose tissue on obesity-induced dysregulation of glucose $\begin{array}{lllllll}\text { metabolism. Am J Physiol Endocrinol Metab 319: } & \text { E607-e613, } 2020 .\end{array}$ https://doi.org/10.1152/ajpendo.00306.2020 
XU H, BARNES GT, YANG Q, TAN G, YANG D, CHOU CJ, SOLE J, NICHOLS A, ROSS JS, TARTAGLIA LA, CHEN H: Chronic inflammation in fat plays a crucial role in the development of obesity-related insulin resistance. J Clin Invest 112, 2003. https://doi.org/10.1172/JCI200319451

YVAN-CHARVET L, WELCH C, PAGLER TA, RANALLETTA M, LAMKANFI M, HAN S, ISHIBASHI M, LI R, WANG N, TALL AR: Increased inflammatory gene expression in ABC transporter-deficient macrophages: free cholesterol accumulation, increased signaling via toll-like receptors, and neutrophil infiltration of $\begin{array}{lll}\text { atherosclerotic lesions. } & \text { Circulation } \\ \text { https://doi.org/10.1161/CIRCULATIONAHA. 108.793869 }\end{array}$

ZEYDA M, FARMER D, TODORIC J, ASZMANN O, SPEISER M, GYORI G, ZLABINGER GJ, STULNIG TM: Human adipose tissue macrophages are of an anti-inflammatory phenotype but capable of excessive pro-inflammatory mediator production. Int J Obes (Lond) 31, 2007. https://doi.org/10.1038/sj.ijo.0803632

ZHANG WY, FRANCO DA, SCHWARTZ E, D'SOUZA K, KARNICK S, REAVEN PD: HDL inhibits saturated fatty acid mediated augmentation of innate immune responses in endothelial cells by a novel pathway. Atherosclerosis 259: 83-96, 2017. https://doi.org/10.1016/j.atherosclerosis.2016.09.003 